\title{
John Allen James: A scholarly remembrance
}

\author{
Christopher L. Hanes • Hugh Rockoff • \\ Mark Thomas • David F. Weiman
}

(C) Springer-Verlag Berlin Heidelberg 2015

John entered the MIT graduate program during the early, lofty days of the "new" economic history, and emerged as one of its most deft, sensible and versatile practitioners. His $\mathrm{PhD}$ dissertation-directed by Peter Temin-exemplifies the promise of this new approach to historical analysis. It addresses a central issue in American political economic development, the formation of a more integrated (or "perfect") money market in the late nineteenth-century. Influenced by the earlier contributions of Lance Davis and Richard Sylla, John set out to document systematically the timing and spatial extent of this financial innovation, and then to explain why it occurred where and when it did. He adapted current finance theory (CAPM) to the historical context by incorporating possible market imperfections due to spatial factors such as local market power. He collected mounds of data on national banks across the country to derive average annual loan rates-the key variable to be explained-over the period 1888-1911.

John's results, subsequently published in his early scholarly articles (one of which was awarded the prestigious Arthur H. Cole prize by the Economic History Association) and then masterfully synthesized in his book Money and Capital Markets in Postbellum America, still constitute the received wisdom on this topic.

C. L. Hanes

SUNY-Binghamton, Binghamton, USA

H. Rockoff

Rutgers University, New Brunswick, USA

M. Thomas

University of Virginia, Charlottesville, USA

D. F. Weiman ( $ه)$

Barnard College, Columbia University, New York, USA

e-mail: dweiman@barnard.edu 
Part of the staying power of John's work can be attributed to the wide range of techniques that he mastered and used. John refined the art of descriptive statistics especially graphical analysis_-or "eye balling the data" in his words-but he also built sophisticated models and tested them using the most current econometric methods. And then true to his calling as both economist and historian, he constructed a compelling narrative showing the interaction between popular (or in the case of regional interest rates, more accurately Populist) politics and banking development. First, he showed that the convergence of bank rates to levels in the Northeast occurred unevenly across the regions of the US. It was most pronounced in the Midwestern and Pacific Coast states, and least evident in the South. The latter observation was the subject of a separate article on Southern financial underdevelopment, and resurfaces in his recent co-authored research on the evolution of the American currency-monetary union. Second, he dated this convergence from the late 1880 s, timing which defied the alternative hypotheses based on the formation of a national commercial paper market (which occurred earlier) and passage of relevant federal banking reforms (in 1900). Finally, his results emphasized the importance of local market power as a factor in explaining the delayed and uneven narrowing of regional interest differentials. Reinforcing this conclusion, John marshaled statistical and qualitative evidence relating the erosion of bank market power to the liberalization of state banking laws in the $1880 \mathrm{~s}$, but only where populist candidates challenged incumbents. Regional differences in the risks of lending, although present, it turned out were of secondary importance in explaining regional differences in interest rates.

John's subsequent research shows his continued fascination with the manifold, profound transformations in the American economy from the Civil War era through the Roaring Twenties. He contributed significantly to the debates over the first and second industrial revolutions in a series of articles on the causes and consequences of technological innovation over the nineteenth century. He first investigated whether labor scarcity induced American manufacturers to adopt more capitalintensive, labor-saving (that is mechanical) innovations. His most widely cited paper on this issue, co-authored with University of Virginia colleague Jonathan Skinner, provided the definitive resolution of the "labor scarcity" paradox, showing that new mechanical technologies substituted for relatively scarce skilled labor but were strategic complements to unskilled labor and natural resources. In turn, the James-Skinner view corroborates empirically an alternative frontier thesis, which emphasizes America's relative abundance of natural resources and not the lure of abundant farm land on labor supplies. Applying a similar production function analysis to the late nineteenth century period, John also furnishes one of the few statistical tests of Alfred Chandler's influential thesis relating shifts in the pattern of technological innovation to the rise of big business.

The James-Skinner article is also noteworthy for its application of general equilibrium simulation modeling in economic history. John had first deployed this methodology in his analysis of US tariff policy before the Civil War. Armed with a new sophisticated - and disconcertingly intractable - technique for deriving general equilibrium outcomes, John corroborates the conventional view on the distributional impacts of antebellum tariffs: all other things equal, they burdened Southern cotton 
exporters but benefitted Northern manufacturers and their workers. At the same time he challenges the mainstream by suggesting that average tariff rates across the period may have been economically "optimal".

John also made many important contributions to the general macroeconomic history of prewar United States. Working solely and with several co-authors including Christopher Hanes, Jon Skinner, and Mark Thomas, John's program embraced pay and wealth inequality during the first industrial revolution; public and private savings behavior and economic growth; unemployment-inflation dynamics and the shifting Phillips curve relationship; and changes in the sources and extent of unemployment and cyclical fluctuations. John's work in these areas appealed to macroeconomists and made use of the latest econometric methods. His 1993 article in the American Economic Review pioneered the use of structural vector autoregression analysis in economic history. A decade later he published another paper in the AER, which used nineteenth century wage data to look for evidence of downward nominal wage rigidity, a phenomenon that had only recently become a focus of research in monetary policy (and has become even more relevant in the post-2008 slump). Though much of John's work in these areas appeared in generalinterest economics journals, it displayed all the virtues of the best economic history. John was careful to account for peculiarities of historical data and institutions, and to point out the implications of his findings for the larger sweep of American social history.

John's foray into the history of US savings tackled thorny questions at the macro and micro levels. Complementing his earlier work on the impact of Civil War debt repayment (or public savings) on late nineteenth century growth, John, in tandem with Skinner, analyzed the dramatic rise in the personal savings rate during the first industrial revolution (published in a volume that placed him among the elite in the profession). True to form, they identified a novel mechanism operating through changes in the occupational rather than the age distribution of the population. And ironically (at least for John), their results downplayed the importance of financial market innovations, such as the spread of deposit banking so important in his earlier work. But typical of John's commitment to following the lead of the data, he could not and did not resist the apparent paradox.

A number of years later John investigated the microeconomics of saving behavior with former Virginia graduate student Michael Palumbo and colleague Mark Thomas. Grounded in the historical equivalent of 'big data'-almost 28,000 observations of late nineteenth century working-class households from Federal and State Bureau of Labor Statistics surveys - they modeled the distribution of savings by age group, derived estimates of the persistence of family income and savings rates over time, and then simulated wealth accumulation by 10,000 model households. Their striking conclusions challenged critics of old-age insurance and working-class profligacy: workers did not save at higher rates in the era before Social Security than in the 1980s. They also showed that few late nineteenth century working class households saved enough before age 65 to meet their living expenses in old age (an expected 10 more years of life), and conjectured that they likely depended on their children, in particular co-habitation with an older son or daughter in the very houses where they had raised their families. Further research revealed 
that workers smoothed their consumption over a medium-period time horizon, indicating the influence of precautionary savings motives in response to a world of considerable riskiness from unemployment, illness, incapacity, and premature death of the household head. Attesting to his growing interest in Japan, John (in work with Isoa Suto) extended this approach to Japanese savings behavior in the era before the social safety net. ${ }^{1}$

John's other major contributions to the micro-economic foundations of macroeconomic outcomes focused on wage and unemployment dynamics in late nineteenth century labor markets. In characteristic fashion, he collected all available data on these topics and then framed questions of historical and current import. Besides challenging earlier research showing signs of nominal wage rigidity, John also investigated and did not find evidence of increasing wage inequality over the period. On the unemployment front, he estimated flows into and out of jobs based on the 1885 Massachusetts census, and found evidence of significant positive duration dependence, for employment and non-employment spells. With a vaster dataset (containing over 100,000 observations), John estimated the natural rate of unemployment in 1909 to be just under six percent, strikingly similar to estimates today. To explain this relatively high rate, his simulation analysis, which divided the labor market into stable-primary and floater-secondary workers, pointed to an eclectic mix of factors: seasonal disturbances for many stable workers, lay-offs for workers in cyclically sensitive sectors, and brief, relatively frequent spells for the floaters. The paper, co-authored with Mark Thomas, won John his second Arthur H. Cole Prize from the Economic History Association. Their joint work also challenged the findings of Christina Romer by showing that unemployment was more cyclically volatile during America's first Gilded Age than it was during its Golden Age (in the post-WWII period). His broader conclusion from these various strands of research is both simple and striking-labor markets and the macro-economy worked differently in the past and historians need to focus on the role of changing institutions and changing policies to try to explain how and why history matters.

Just prior to his sudden and untimely death, John returned to a topic briefly addressed in his dissertation and subsequent book on banking-financial markets in postbellum America. At a St. Louis Fed conference, he presented data showing the increased efficiency of a largely private, decentralized banking system in greasing the wheels of commerce by moving money from one location to another, even across the country, at relatively low cost. Teaming up with David Weiman, they explained this trend by the formation of a tiered network of correspondent banks centered on New York.

James and Weiman elaborated this initial paper into a book-length project to explain the evolution of this neglected economic infrastructure from the demise of the Second Bank of the United States to the formation of the Fed. Informed by current policy debates, they conceived these transformations in terms of the "benefits and costs" of alternative institutional forms-private versus public and hierarchical networks versus bureaucracies. En route, they decided to write on the

\footnotetext{
${ }_{1}^{1}$ John had earlier explored the different historical savings patterns in Japan and the US and their implications for economic growth.
} 
Civil War era banking legislation, which institutionalized the emerging private correspondent banking network. Their initial foray uncovered a striking connection between the adoption of a common currency and a longer-term trend toward a "more perfect" bank money (or payments) union.

Armed with this serendipitous result, James and Weiman have broadened the scope of their project to show the complex interplay between the "punctuated" evolution of the interbank payment network and the American monetary union. Conceived along these lines, their book (in progress with a manuscript expected by the end of 2015) will complete what for John was a lifetime's exploration of the development of the banking system in postbellum America. Banks, we know, are peculiar financial institutions, both credit and payments intermediary. John's first book Money and Capital Markets analyzed their former dimension, and his forthcoming book will attend to the latter.

John's scholarly contributions cannot be measured solely by his outstanding research record. He was an academic mensch, to use a most fitting Yiddish expression. John never refused the thankless tasks of a productive scholar-the endless referee reports, book reviews and discussant comments-but even when critical, he always struck a constructive tone sweetened with a good dose of his dry wit. (In the case of the role, we should also note that ever the cosmopolitan John would rarely pass up the opportunity to venture far and wide to see new sites and especially opera productions). But John's spirit truly shone through in his interactions with younger scholars from all walks of intellectual life. He was an intellectual gourmand ever curious to broaden his own substantive and theoretical-methodological horizons, but also a genuinely gifted mentor who guided others down their own paths, not his own. And he was always ready to share his data, and willing to explain how to use them. This aspect of John's career can be best measured by the outpouring of affection from his "juniors," who now can proudly call him a colleague, collaborator, and friend. And they all describe him in virtually identical terms: brilliant, probing, curious, supportive, generous, decent, kind, humane, compassionate and passionate. We are sure that this list is not complete but can attest to one fact. John will be sorely missed by all of those whose lives he touched so profoundly.

\section{Selected highlights from John's career}

"Payment Systems". In: Claude Diebolt, Michael Haupert, eds., Handbook of Cliometrics, Berlin: Springer Verlag, 2015, in press.

"Political Economic Limits to the Fed's Goal of a Common National Bank Money: The Par Clearing Controversy Revisited" (with David F. Weiman). Research in Economic History, 30 (2014), pp. 91-134.

"Main Street and Wall Street: The Macroeconomic Consequences of New York Bank Suspensions, 1866 to 1914" (with David F. Weiman and James A. McAndrews), Cliometrica, 7 (January, 2013), pp. 99-130.

"The National Banking Act and the Transformation of New York after the Civil War" (with David F. Weiman), Journal of Economic History, 71 (June, 2011), pp. 340-364. 
"Early Twentieth-Century Japanese Worker Saving: Precautionary Behavior before a Social Safety Net" (with Isao Suto), Cliometrica, 5 (January, 2011), pp. $1-25$.

"From Drafts to Checks: The Evolution of Correspondent Banking Networks and the Formation of the Modern U.S. Payments System, 1850-1914" (with David F. Weiman), Journal of Money, Credit, and Banking, 42 (April, 2010), pp. 237-265.

"Consumption Smoothing among Working-Class American Families before Social Insurance" (with Michael Palumbo and Mark Thomas), Oxford Economic Papers, 59 (October, 2007), pp. 606-640.

"The Political Economy of the U.S. Monetary Union: The Civil War Era as a Watershed" (with David F. Weiman), American Economic Review Papers and Proceedings, 97 (May, 2007), pp. 271-275.

"Romer Revisited: Long-term Changes in the Cyclical Sensitivity of Unemployment" (with Mark Thomas), Cliometrica, 1 (April, 2007), pp. 19-44.

"Have American Workers Always Been Low Savers?" Patterns of Accumulation among Working-Class Households, 1885-1910," (with Mark Thomas and Michael Palumbo), Research in Economic History, 23 (2005), pp. 127-175.

"Financial Clearing Systems" (with David F. Weiman). In Richard Nelson, ed., Limits of Market Organization, New York: Russell Sage, 2005. pp. 114-155.

"A Golden Age? Unemployment and the American Labor Market, 1880-1910" (with Mark Thomas), Journal of Economic History, 63 (December, 2003), pp. 959-994.

"Wage Adjustment under Low Inflation: Evidence from U.S. History" (with Christopher L. Hanes), American Economic Review, 93 (September, 2003), pp. 1414-1424.

"Industrialization and Wage Inequality in Nineteenth-Century Urban America" (with Mark Thomas), Journal of Income Distribution, 9 (2000), pp. 39-64.

"Savings and Early Economic Growth in the United States and Japan," Japan and the World Economy, 11 (1999), pp. 161-83.

"The Early History of Nominal Wage Rigidity in American Industrial Labor Markets," Rivista di Storia Economica, 14 (December, 1998), pp. 243-73.

"The Rise and Fall of the Commercial Paper Market, 1900-1930." In: M. Bordo and R. Sylla, eds., Anglo-American Finance: Financial Markets and Institutions in 20th Century North America and the UK, Homewood, IL: Dow Jones-Irwin, 1996. pp. 219-59.

"Reconstructing the Pattern of American Unemployment Before World War I," Economica, 62 (August, 1995), pp. 291-311.

"Job Tenure in the Gilded Age." In: George Grantham and Mary MacKinnon eds., Labour Market Evolution, London: Routledge Kegan Paul, 1994. pp. 185-204.

Capitalism in Context: Essays on Economic Development and Cultural Change in Honor of R. M. Hartwell, ed. (with Mark Thomas). Chicago: University of Chicago Press, 1994.

"Economic Instability in Nineteenth-Century America," American Economic Review, 83 (September, 1993), pp. 710-31.

"The Stability of the Nineteenth-Century Phillips Curve Relationship," Explorations in Economic History, 26 (April, 1989), pp. 117-34. 
"Sources of Savings in the Nineteenth-Century United States" (with Jonathan Skinner). In: Peter Kilby, ed., Quantity and Quiddity: Essays in U.S. Economic History in Honor of Stanley Lebergott, Middletown, CT: Wesleyan University Press, 1987, pp. 255-285.

"The Resolution of the Labor Scarcity Paradox," (with Jonathan Skinner), Journal of Economic History, 45 (September, 1985), pp. 513-540.

"The Use of General Equilibrium Analysis in Economic History," Explorations in Economic History, 21 (July, 1984), pp. 231-253.

"Public Debt Management Policy and Nineteenth-Century American Economic Growth," Explorations in Economic History, 21 (April, 1984), pp. 192-217.

"Structural Change in American Manufacturing, 1850-1890," Journal of Economic History, 42 (June, 1983), pp. 433-460.

"The Optimal Tariff in the Antebellum United States," American Economic Review, 71 (September, 1981), pp. 726-734.

"Some Evidence on Relative Labor Scarcity in Nineteenth-Century American Manufacturing," Explorations in Economic History, 18 (September, 1981), pp. 376-88.

"Financial Underdevelopment in the Postbellum South," Journal of Interdisciplinary History, 11 (Winter, 1980), pp. 443-54.

"Cost Functions of Postbellum National Banks," Explorations in Economic History, 15 (April, 1978), pp. 184-95.

"The Welfare Effects of the Antebellum Tariff: A General Equilibrium Analysis," Explorations in Economic History, 15 (July, 1978), pp. 231-56.

Money and Capital Markets in Postbellum America. Princeton: Princeton University Press, 1978.

"Banking Market Structure, Risk, and the Pattern of Local Interest Rates in the United States, 1893-1911," Review of Economics and Statistics, 58 (November, 1976), pp. 453-62.

"The Conundrum of the Low Issue of National Bank Notes," Journal of Political Economy, 84 (April, 1976), pp. 359-67.

"The Development of the National Money Market," Journal of Economic History, 36 (December, 1976), pp. 878-97.

"Portfolio Selection with an Imperfectly Competitive Asset Market," Journal of Financial and Quantitative Analysis, 11 (December, 1976), pp. 831-46. 